\title{
QUANTIFICATION OF BERGENIN, ANTIOXIDANT ACTIVITY AND NITRIC OXIDE INHIBITION FROM BARK, LEAF AND TWIG OF Endopleura uchi
}

\author{
Magno P. Muniz ${ }^{a, *(\odot), ~ S e r g i o ~ M . ~ N u n o m u r a ~}{ }^{c}$ Emerson S. Lima $^{\mathrm{b}}$, Arleilson S. Lima ${ }^{\mathrm{b}}$, Patrícia D. O. de Almeida ${ }^{\mathrm{b}}$ and Rita \\ C. S. Nunomura ${ }^{a}$ \\ aDepartamento de Química, Instituto de Ciências Exatas, Universidade Federal do Amazonas, 69077-000 Manaus - AM, Brasil \\ ${ }^{b}$ Faculdade de Ciências Farmacêuticas, Universidade Federal do Amazonas, 69080-900 Manaus - AM, Brasil \\ 'Coordenação de Pesquisa de Tecnologia e Inovação, Instituto Nacional de Pesquisas da Amazônia, 69067-375 Manaus - AM, Brasil
}

Recebido em 11/09/2019; aceito em 22/01/2020; publicado na web em 06/04/2020

\begin{abstract}
Phytochemical investigation of Endopleura uchi led to the isolation of a gallic acid derivate, known as bergenin (2) and friedelin (1), a pentacyclic triterpene. The present work also reports the bergenin quantification in different Endopleura uchi bark, twig and leaves extracts. Our findings showed the highest bergenin concentration in bark methanol extracts $(4.75 \%)$ and the lowest concentration in twig aqueous extracts (1.89\%). Phenolics quantification by Folin-Ciocalteu, revealed phenolic compounds level values from 16.69 to $43.02 \mathrm{mg} \mathrm{GAE} \mathrm{g}^{-1}$ dry extract. The ferric reducing antioxidant activity ranged from 230.43 to $567.89 \mathrm{mmol} \mathrm{Fe}^{+2} \mathrm{~g}^{-1}$ dry extract. DPPH $\mathrm{IC}_{50}$ free radicals showed to range from 12.04 to $24.20 \mu \mathrm{g} \mathrm{mL}^{-1}$. Leaves' chloroform fraction exhibited the highest nitric oxide inhibiting activity bearing $\mathrm{IC}_{50}=3.2 \mu \mathrm{g} \mathrm{mL}^{-1}$. Results show this species to hold significant bergenin concentrations as well as phenolic and anti-inflammatory compounds in all extracts suggesting it bear therapeutic potential.
\end{abstract}

Keywords: Humiriaceae; liquid chromatography; anti-inflammatory agents; natural products; DPPH.

\section{INTRODUCTION}

Species Endopleura uchi (Huber) Cuatrec. [sin. Sacoglottis uchi Huber] belongs to the Humiriaceae family and is typically wild in primary forests growing on non-flooded land, widely dispersed throughout the Amazon Basin. It is mainly found in the state of Amazonas, and popularly known as "uxi-amarelo", "uxi-liso", "uxi-pucu" and "pururu"., Endopleura uchi barks have been sold in open fairs, markets, nationwide online shops and commercial natural products outlets and used in the form of tea as a potent antiinflammatory medicine against tumors, myomas, uterine infections, fibroids and polycystic ovaries. ${ }^{3}$ Friedelin, a pentacyclic triterpene, and a 4-O-methyl gallic acid C-glycoside derivate known as bergenin, both bearing anti-inflammatory properties (Figure 1). ${ }^{4,5}$ Bergenin shows activity against the growth of yeast for different Candida species, ${ }^{6}$ inhibitory activity against COX $-2,{ }^{7}$ which is an enzyme mediating inflammatory processes in the body, antioxidant activity, ${ }^{8}$ hepatoprotective, ${ }^{9}$ neuroprotective, ${ }^{10}$ anti-HIV ${ }^{11}$ and antifungal activities against complete inhibition of germination of spores of Fusarium udum and Erysiphe pisi. ${ }^{12}$ Earlier studies have reported the isolation of bergenin from the aqueous extract of the bark of Endopleura uchi of about $3.19 \%,{ }^{7}$ in fruits and in other species of the family Humiriaceae as Humiria balsamifera Aubl. and Sacoglottis gabonensis. ${ }^{13,14}$ The several bergenin biological activities have led this work toward the bergenin quantification in different Endopleura uchi leaves, twigs and bark extracts through RP-HPLC to find out the active principle concentration in different parts of the species.

Considering the sp., Endopleura uchi popular use as antiinflammatory medicine and on account of this inflammatory process being associated with oxidative stress, extracts and fractions antioxidant activity and free radicals scavenging ability, were evaluated through the FRAP (ferric reducing antioxidant power) and DPPH (2,2-diphenyl-1picrylhydrazyl) methodologies, respectively. Furthermore, the content of phenolic compounds, which are known for their ability to prevent

*e-mail: gno.perea@gmail.com oxidative stress that yields reactive oxygen (ROS) and nitrogen (RNS) species, causing physiological alterations and even cell death, have been determined. ROS and RNS can be generated by external factors or, within the organism, by neutrophils and macrophages during the inflammatory action. ${ }^{15}$ A method was employed to estimate Endopleura uchi extracts ability to suppress nitric oxide (NO), an inflammation mediator, production in LPS (lipopolysaccharide)-induced J774 murine macrophages cultures, for assessing their anti-inflammatory aspect. ${ }^{16}$

Earlier studies in the literature on the species Endopleura uchi have just been targeted on its fruits and barks. This paper also discusses unpublished studies addressing Endopleura uchi twigs and leaves, which have presented relevant aspects that may contribute to the development of new drugs or herbal medicines. The scientific research of this species through understanding their chemical constituents and confirmed biological activity can direct the popular use to another part of the plant since the inadequate extraction of tree bark can result in the death of the species. ${ }^{17}$

\section{EXPERIMENTAL SECTION}

\section{Solvents, reagents and chemicals}

All solvents used were of HPLC grade by J. T. Baker (Xalostoc, Edo. Mexico). Water was purified using a Milli-Q system (Millipore®, Berdford, USA). Folin-Ciocalteu, 2,2-diphenyl-1-picrylhydrazyl (DPPH), quercetin; gallic acid; (Sigma-Aldrich, Inc, St. Louis, Missouri, USA); sodium bicarbonate, ferrous sulphate heptahydrate and ferric chloride III (Synth, Diadema, SP, Brazil); 2,4,6-tri(2pyridyl)-s-triazine (TPTZ) (Fluka Chemie GmbH, Buchs, $\mathrm{CH}$ ); hydrochloric acid and trifluoroacetic acid (Tedia, Fairfield, OH, USA); ion (II) chloride tetrahydrate (Merck, Darmstadt, $\mathrm{GmbH}$ ).

\section{Plant material}

Leaves, twigs and barks of the species Endopleura uchi identified by botanist $\mathrm{G}$. T. Prance and deposited in the herbarium of the INPA 
under the number 190992 were collected at Adolpho Ducke Reserve (INPA) located at Km 23 from Manaus (AM) during the dry period on October 11, 2010 and the rainy season on April 16, 2011. This project has been registered with the National Genetic Resource Management and Associated Traditional Knowledge Management System (SisGen - A04356A).

\section{General experimental procedures}

The NMR spectra were obtained on a Unity Inova spectrometer model $500 \mathrm{MHz}\left({ }^{1} \mathrm{H} \mathrm{NMR}\right)$ and $125 \mathrm{MHz}\left({ }^{13} \mathrm{C} \mathrm{NMR}\right)$ in $\mathrm{CDCl}_{3}$ or $\mathrm{CD}_{3} \mathrm{OD}$ (Cambridge Isotope Laboratories Inc.). HR-ESI-MS and HR-APCI-MS analyses were measured in the positive ion mode (Bruker Daltonics, model II - TOF, APCI). Column chromatography was performed on silica LC60A (70 - $200 \mathrm{~mm}$, Grace) and silica 60 (40 - $63 \mu \mathrm{m}$, Merck). Melting points (uncorrected) were recorded on a FISATOM 430 D Melting Point Apparatus.

\section{Extraction}

Leaves (F), twigs $(\mathrm{G})$ and barks $(\mathrm{C})$ were ground and dried. Aqueous extracts (EA) were prepared by decoction of $30 \mathrm{~g}$ of dried plant material in $500 \mathrm{~mL}$ boiling distilled water for $5 \mathrm{~min}$ as the popular use. Methanol extracts (EM) were prepared by soxhlet extraction, the solvent replaced every 6 hours, totaling $18 \mathrm{~h}$ of extraction. Ethanol extract (EE) prepared by using $40 \mathrm{~g}$ of dried plant material in $400 \mathrm{~mL}$ of ethanol three times in ultrasound for $15 \mathrm{~min}$ each, followed by maceration for one day.

\section{Friedelin and bergenin isolation}
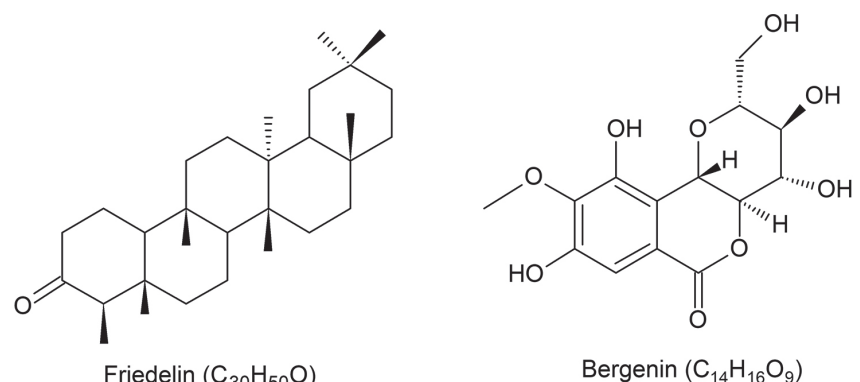

Bergenin $\left(\mathrm{C}_{14} \mathrm{H}_{16} \mathrm{O}_{9}\right)$

Figure 1. Structures of friedelin and bergenin

Friedelin was isolated from twigs and leaves hexane fractions. Bergenin was isolated from barks, twigs and leaves ethyl acetate fractions. Compounds were identified by ${ }^{1} \mathrm{H},{ }^{13} \mathrm{C}$ NMR, HOMOCOSY, HSQC, HMBC and MS spectrometry. Twigs (GEM-1, 9.6 g), leaves (FEM-1, $10.0 \mathrm{~g}$ ) and barks (CEM-1, $13.8 \mathrm{~g}$ ) methanol extracts prepared in liquid-liquid extraction solubilized in methanol/water (9:1) and partitioned with hexane, chloroform and ethyl acetate, successively. The hexane phase of twigs (GEM-1-Hex, $260.0 \mathrm{mg}$ ) was concentrated and then recrystallized with acetone that resulted in impure crystals. These crystals were purified by chromatographic column in silica gel $60(40-63 \mu \mathrm{m})$, using hexane/chloroform gradient $(7: 3,1: 1,3: 7)$ and chloroform $(100 \%)$ as mobile phase to yield friedelin (1) $(5.0 \mathrm{mg})$. The same procedure was performed with leaves hexane fraction (FEM-1-Hex, $500.0 \mathrm{mg}$ ) to yield friedelin (1) $(17.5 \mathrm{mg})$. The ethyl acetate phase (GEM-1-EtOAc, $1.87 \mathrm{~g}$ ) concentrated and washed with acetone that resulted in a crystalline solid impure. This material was separated in a chromatographic column using silica gel LC60A (70-200 $\mu \mathrm{m})$ and chloroform/ethanol (7:3) isocratic as the mobile phase to yield bergenin (2) $(550.0 \mathrm{mg})$. The same procedure was both carried out with leaves ethyl acetate fraction (FEM-1-EtOAc, $1.7 \mathrm{~g}$ ) to yield bergenin (2) (540.0 mg) and barks ethyl acetate fraction (CEM-1-EtOAc, $2.5 \mathrm{~g}$ ) to yield bergenin (2) $(840.0 \mathrm{mg})$.

Friedelin ${ }^{18}(\mathbf{1})$ : White crystalline solid; m.p: $252-255{ }^{\circ} \mathrm{C} ;{ }^{1} \mathrm{H}$ $\delta_{\mathrm{H}}\left(500 \mathrm{MHz}, \mathrm{CDCl}_{3}\right): 1.97(m, \mathrm{H}-1 \mathrm{a}), 1.69(1 \mathrm{H}, d d, J=5.0$ and $13.0 \mathrm{~Hz}, \mathrm{H}-1 \mathrm{~b}), 2.39$ (1H, ddd, $J=2.0,5.0,14.0 \mathrm{~Hz}, \mathrm{H}-2 \mathrm{a}), 2.30$ $(1 \mathrm{H}, d d, J=7.5,13.5 \mathrm{~Hz}, \mathrm{H}-2 \mathrm{~b}), 2.25(1 \mathrm{H}, q, J=6.5 \mathrm{~Hz}, \mathrm{H}-4), 1.76$ $(1 \mathrm{H}, d d, J=3.0,16.0 \mathrm{~Hz}, \mathrm{H}-6 \mathrm{a}), 1.28$ ( $m, \mathrm{H}-6 \mathrm{~b}), 1.60$ ( $m, \mathrm{H}-7 \mathrm{a})$, 1.48 ( $m, \mathrm{H}-7 \mathrm{~b}), 1.45$ ( $m, \mathrm{H}-8 \mathrm{a}), 1.40$ ( $m, \mathrm{H}-8 \mathrm{~b}), 1.56$ ( $m, \mathrm{H}-10)$, 1.39 ( $m, \mathrm{H}-11), 1.36$ ( $m, \mathrm{H}-12), 1.48$ ( $m, \mathrm{H}-15 \mathrm{a}), 1.28$ ( $m, \mathrm{H}-15 \mathrm{~b})$, 1.55 ( $m, \mathrm{H}-16 \mathrm{a}), 1.37$ ( $m, \mathrm{H}-16 \mathrm{~b}), 1.57$ ( $m, \mathrm{H}-18), 1.38$ ( $m, \mathrm{H}-19)$, 1.50 ( $m, \mathrm{H}-21), 1.49$ ( $m, \mathrm{H}-22), 0.88(3 \mathrm{H}, d, J=6.5 \mathrm{~Hz}, \mathrm{H}-23)$, 0.73 (3H, s, H-24), 0.89 (3H, s, H-25), 1.01 (3H, s, H-26), 1.05 $(3 \mathrm{H}, s, \mathrm{H}-27), 1.18(3 \mathrm{H}, s, \mathrm{H}-28), 1.00(3 \mathrm{H}, s, \mathrm{H}-29)$ and $0.96(3 \mathrm{H}$, $s, \mathrm{H}-30) ;{ }^{13} \mathrm{C} \delta_{\mathrm{C}}\left(125 \mathrm{MHz}, \mathrm{CDCl}_{3}\right): 22.6(\mathrm{C}-1), 41.8(\mathrm{C}-2), 213.5$ (C-3), 58.5 (C-4), 42.4 (C-5), 41.6 (C-6), 18.5 (C-7), 53.6 (C-8), 37.8 (C-9), 59.8 (C-10), 35.9 (C-11), 30.8 (C-12), 40.0 (C-13), 38.6 (C-14), 33.1 (C-15), 36.3 (C-16), 30.3 (C-17), 43.1 (C-18), 35.7 (C-19), 28.5 (C-20), 32.7 (C-21), 39.6 (C-22), 7.1 (C-23), 15.0 (C-24), 18.2 (C-25), 20.6 (C-26), 19.0 (C-27), 32.4 (C-28), 32.1 (C-29) and 35.3 (C-30); HR-APCI-TOF-MS: $427.3942[\mathrm{M}+\mathrm{H}]^{+}$, $\mathrm{C}_{30} \mathrm{H}_{51} \mathrm{O}^{+}$; calc. 427.3934 .

Bergenin $^{5,7}(2)$ : White crystalline solid; m.p: $150-152{ }^{\circ} \mathrm{C}^{19} ;{ }^{1} \mathrm{H} \delta_{\mathrm{H}}$ (500 MHz, CD $\mathrm{OD}): 7.08$ (1H, s, H-4), $4.95(1 \mathrm{H}, d, J=10 \mathrm{~Hz}, \mathrm{H}-9)$, 3.69 (1H, $m, \mathrm{H}-11), 3.43(1 \mathrm{H}, d d, J=8.5,8.5 \mathrm{~Hz}, \mathrm{H}-12), 3.81(1 \mathrm{H}$, $d d, J=8.8,9.5 \mathrm{~Hz}, \mathrm{H}-13), 4.06(1 \mathrm{H}, d d, J=9.5,10.0 \mathrm{~Hz}, \mathrm{H}-14), 3.91$ $(3 \mathrm{H}, s, \mathrm{H}-15), 3.68(1 \mathrm{H}, m, \mathrm{H}-16), 4.02(1 \mathrm{H}, d d, J=3.0,13.0 \mathrm{~Hz}$, $\mathrm{H}-16) .{ }^{13} \mathrm{C} \delta_{\mathrm{C}}\left(125 \mathrm{MHz}, \mathrm{CD}_{3} \mathrm{OD}\right): 164.6(\mathrm{C}-2), 118.2$ (C-3), 109.9 (C-4), 151.1 (C-5), 141.1 (C-6), 148.2 (C-7), 116.1 (C-8), 73.1 (C-9), 81.9 (C-11), 70.7 (C-12), 74.4 (C-13), 80.2 (C-14), 59.8 (C-15), 61.5 (C-16). HR-ESI-TOF-MS: $329.0866[\mathrm{M}+\mathrm{H}]^{+}, \mathrm{C}_{14} \mathrm{H}_{17} \mathrm{O}_{9}{ }^{+}$; calc. 329.0867 .

\section{Total phenolics determination}

The Folin-Ciocalteu ${ }^{20}$ method was used to quantify the total phenolic content in extracts and fractions. Two-hundred (200) $\mu \mathrm{L}$ of the sample $\left(1 \mathrm{mg} \mathrm{mL}^{-1}\right.$ in methanol) were mixed with $1.5 \mathrm{~mL}$ of aqueous solution of Folin-Ciocalteau (1:10). Following $5 \mathrm{~min}$, $1.5 \mathrm{~mL}$ of sodium bicarbonate $\left(\mathrm{Na}_{2} \mathrm{CO}_{3}, 6 \%\right)$ solution added. Then, after it incubated at room temperature for $90 \mathrm{~min}$, the absorbance was measured at $725 \mathrm{~nm}$ in a UV/Vis spectrophotometer (Femto 800XI) and Milli-Q water used as blank. The analyses were performed in triplicate and the total phenolic content mean was expressed in milligrams of gallic acid equivalents (GAE) per gram of dry extract. Gallic acid analytical curve was constructed in the range of $15.6-250 \mu \mathrm{g} \mathrm{mL} \mathrm{H}^{-1}\left(\mathrm{y}=4.9604 \mathrm{x}-0.0428, \mathrm{R}^{2}=0.9986\right)$.

\section{DPPH free radical scavenging through antioxidant activity}

DPPH free radical scavenging capacity was measured by the photometric method described by Mensor. ${ }^{21}$ For each fraction, extract or standard (quercetin) six different dilutions were prepared (4-57 $\mathrm{mg} \mathrm{mL}^{-1}$ in methanol, $\left.2.5 \mathrm{~mL}\right)$ and $1 \mathrm{~mL}$ of DPPH $\left(0.2 \mathrm{mg} \mathrm{mL}^{-1}\right)$ added. After $30 \mathrm{~min}$, in the dark at room temperature, a reading was taken at $518 \mathrm{~nm}$ in a spectrophotometer (Femto 800XI). Blank was obtained by the higher concentration samples and $2.5 \mathrm{~mL}$ methanol in $1 \mathrm{~mL}$ of DPPH as a negative control. The antioxidant activity was calculated as follows:

$\mathrm{AA} \%=100-[($ Abs sample - Abs blank $) /$ Abs control $] \times 100$ 
where, Abs sample $=$ average absorbance of the sample, Abs blank $=$ absorbance of the higher concentration sample, Abs control $=$ average absorbance of the negative control. The $50 \%$ inhibitory capacity $\left(\mathrm{IC}_{50}\right)$ was calculated from the slope with antioxidant activity versus sample concentration, which analyses were performed in triplicate.

\section{Antioxidant activity by FRAP method (ferric reducing antioxidant power)}

The FRAP assay was performed as described by LuximonRamman. ${ }^{22}$ The FRAP reagent was prepared fresh by mixing in $10 \mathrm{mM}$ TPTZ (2,4,6-tripiridyl-triazine), $20 \mathrm{mM}$ of iron (III) chloride solution and sodium acetate buffer $(0.25 \mathrm{M}, \mathrm{pH} 3.5)$ at a ratio of 1:1:10. Then, $100 \mu \mathrm{L}$ of the sample in methanol $\left(1 \mathrm{mg} \mathrm{mL}^{-1}\right)$ were added to $300 \mu \mathrm{L}$ of Milli-Q water and $3.0 \mathrm{~mL}$ of FRAP reagent. The absorbance was measured at $593 \mathrm{~nm}$ after being incubated for 4 minutes. Findings were expressed as $\mathrm{Fe}^{+2} \mu \mathrm{mol} \mathrm{g}{ }^{-1}$ dry weight of plant material and the analytical curve was constructed using $\mathrm{FeSO}_{4}$ $\left(62.5-2000 \mu \mathrm{mol} \mathrm{L}^{-1} ; \mathrm{y}=0.0007 \mathrm{x}-0.0428, \mathrm{R}^{2}=0.9999\right)$.

\section{Cell culture and treatments}

Murine macrophages $\mathrm{J} 774$ cells (donated from the cell bank of the Rio de Janeiro) were grown at $37^{\circ} \mathrm{C}$ in an incubator containing $5 \%$ $\mathrm{CO}_{2}$ in RPMI-1640 medium included fetal bovine serum (10\%, FBS), streptomycin $\left(50 \mu \mathrm{g} \mathrm{mL}^{-1}\right.$, Invitrogen $)$ and penicillin $\left(50 \mathrm{U} \mathrm{mL}^{-1}\right)$. The used LPS stock solution $\left(1 \mathrm{mg} \mathrm{mL}^{-1}\right)$ was prepared in sterile PBS [137.0 mM NaCl, $2.7 \mathrm{mM} \mathrm{KCl}, 4.3 \mathrm{mM} \mathrm{Na} \mathrm{HPO}_{4} .7 \mathrm{H}_{2} \mathrm{O}, 1.4 \mathrm{mM}$ $\mathrm{KH}_{2} \mathrm{PO}_{4}, \mathrm{pH}$ 7.4]. LPS is used to stimulate iNO in cells. Samples were added to the culture medium before LPS treatment. ${ }^{23}$

\section{NO production assay}

After pre-incubation of cells $\left(1 \times 10^{6}\right.$ cells $\left.\mathrm{mL}^{-1}\right)$ with differently concentrated samples ( 2.5 to $25.0 \mu \mathrm{g} \mathrm{mL}^{-1}$ ) for $2 \mathrm{~h}$, cells were incubated for 24 hours either with or without LPS $\left(1 \mathrm{mg} \mathrm{mL}^{-1}\right)$ at $37^{\circ} \mathrm{C}$ in an incubator containing $5 \% \mathrm{CO}_{2}$. The same procedure was carried out for negative control and blank. Then, nitric oxide production $\left(\mathrm{NO}_{2}\right)$ in the culture supernatant was determined using Griess reagent ${ }^{23}$ in triplicate. Samples absorbance was measured at $560 \mathrm{~nm}$ using a microplate reader (DTX 800, Beckman). Sodium nitrite was used as a standard to calculate nitrite concentrations.

\section{Bergenin quantification}

Endopleura uchi extracts bergenin quantification was performed using a method previously described by Nunomura et al. ${ }^{7}$ with some modifications. Analyses were performed by Liquid Chromatography using a SHIMADZU Prominence LC-20A, equipped by LC-10AT Vp quaternary pump, automatic injector SIL-20A and DAD detector (DAD) SPD-M20A and data process using a LC-Solution software. The separation was performed in a Merck LiChrospher $100 \mathrm{RP}$ $18 \mathrm{e}(250 \mathrm{~mm} \times 4.0 \mathrm{~mm}, 5 \mu \mathrm{m}$ and $120 \mathrm{~A}$ ) column using, methanol as solvent $\mathrm{B}(20 \%)$ and THF solution in water ( $\mathrm{pH} 2.0)$ as solvent A $(80 \%)$, as mobile phase during 30 minutes. The mobile phase was degassed before analyses. The flow rate was $1.0 \mathrm{~mL} \mathrm{~min}{ }^{-1}$ and detection on 215, 254 and $272 \mathrm{~nm}$. The column temperature was $25^{\circ} \mathrm{C}$ and the injection volume $50 \mu \mathrm{L}$. The quantification was performed by integrating peaks using bergenin, as an external standard, diluted in methanol at $6.25,12.5,25.0,50.0,100.0$ and $200.0 \mu \mathrm{g} \mathrm{mL}^{-1}$ concentrations, analyzed intra-day and inter-day $\left(\mathrm{R}^{2}>0.995\right)$, in duplicate. Extracts were submitted to SPE using C18 cartridge (Sep-Pak) and analyzed at $250 \mu \mathrm{g} \mathrm{mL}^{-1}$ in duplicate. Extract sample peaks identification was performed by comparison with bergenin by retention time and $\lambda \max$ in $\mathrm{nm}$. Extract and standard samples were filtered on $0.2 \mu \mathrm{m}$ Millipore membrane.

\section{RESULTS AND DISCUSSION}

\section{Bergenin quantification}

Bergenin (2) was quantified in leaves, twigs and barks from Endopleura uchi by High Performance Liquid ChromatographyDiode Array Detector (HPLC-DAD) on aqueous and methanol extracts using Nunomura et al..$^{7}$ method and some modifications. Bergenin standard solutions $\left(6.25-200 \mu \mathrm{g} \mathrm{mL} \mathrm{mL}^{-1}\right)$ were analyzed repeatedly intraday and interday and resulted in an excellent linear regression slope $\left(\mathrm{R}^{2}>0.995, \mathrm{CV}<5 \%\right.$ ) (Supplementary Material Table $1 \mathrm{~S}$ and Figure 12S). Detection and quantification limits (DL) and (QL) showed a high detection level in addition to sensitivity for both bergenin quantification and trace analysis (Table 1).

Methanol and aqueous extracts from Endopleura uchi collected in the dry period $\left(1^{\text {st }}\right.$ collect $)$ and rainy period $\left(2^{\text {nd }}\right.$ collect $)$ were analyzed at $250 \mu \mathrm{g} \mathrm{mL}^{-1}$. The quantification of bergenin in Endopleura uchi extracts were performed using the calibration slope with detection at $272 \mathrm{~nm}$ (Supplementary Material Table 2S). Bergenin was identified in chromatogram extracts by comparison with the chromatogram of the standard using UV parameters with $\lambda \max 215,254$ and $272 \mathrm{~nm}$ and retention time at $11 \mathrm{~min}$. The concentration of bergenin in dried bark (\%) was determined using the yield of extracts (\%) at Table 2.

Both dry and wet season extracts exhibit similar bergenin concentrations. Each extract showed similar extractive and bergenin levels when dry and rainy seasons have to be compared. When bergenin concentration is compared between methanol and aqueous extracts, one finds the extraction using methanol to yield a higher bergenin concentration, though in aqueous extracts it showed to be about $10 \%$ lower than in leaves methanol extracts and $30 \%$ lower than in bark and twigs methanol extracts. Therefore, these findings indicate aqueous extracts to bear high bergenin concentration, especially the leaves aqueous extracts that show similar to methanol extracts values. The mean barks aqueous extracts bergenin concentration in dry season and rain season showed to be similar to that reported in Nunomura et al., ${ }^{7}$ that showed a concentration of $3.19 \%$. The lower concentration of bergenin is observed in aqueous extract of twigs with an average concentration of $1.9 \%$. These findings indicate bergenin to be the Endopleura uchi main component being found in all parts of the plant and possibly its active principle that is used as a medicinal

Table 1. Curve data of standard solutions of bergenin $\left(6.25-200 \mu \mathrm{g} \mathrm{mL}^{-1}\right)$

\begin{tabular}{|c|c|c|c|c|}
\hline$\lambda(\mathrm{nm})$ & Equation curve $^{\text {a }}$ & Linear coefficient $\left(\mathrm{R}^{2}\right)$ & $\mathrm{DL}^{\mathrm{b}}$ & $\mathrm{QL}^{\mathrm{c}}$ \\
\hline 272 & $y=66.349,9399 x-17.824,6393$ & 1.000 & 9.85 & 29.84 \\
\hline 254 & $y=36.770,1945 x-4.814,1791$ & 1.000 & 8.88 & 26.92 \\
\hline 215 & $y=242.018,3217 x-956.260,4163$ & 0.996 & 0.78 & 2.37 \\
\hline
\end{tabular}

${ }^{\mathrm{a}}$ Six points $\left(\mathrm{n}=2\right.$, interday and intraday). ${ }^{\mathrm{b}}$ Detection limits $\left(\mu \mathrm{g} \mathrm{mL}^{-1}\right)$. ${ }^{\mathrm{c}}$ Quantification limits $\left(\mu \mathrm{g} \mathrm{mL} \mathrm{L}^{-1}\right)$. 
Table 2. Quantification of bergenin in different Endopleura uchi extracts with detection at $272 \mathrm{~nm}$

\begin{tabular}{|c|c|c|c|c|c|}
\hline \multicolumn{2}{|c|}{ Barks } & \multicolumn{2}{|c|}{ Twigs } & \multicolumn{2}{|c|}{ Leaves } \\
\hline Extract $^{\mathrm{a}}$ & Bergenin $(\% \pm \mathrm{CV})^{\mathrm{b}}$ & Extract $^{\mathrm{a}}$ & Bergenin $(\% \pm \mathrm{CV})^{\mathrm{b}}$ & Extract $^{\mathrm{a}}$ & Bergenin $(\% \pm \mathrm{CV})^{\mathrm{b}}$ \\
\hline CEA-1 & $3.31 \pm 0.4$ & GEA-1 & $1.95 \pm 1.0$ & FEA-1 & $3.24 \pm 2.0$ \\
\hline CEA-2 & $2.87 \pm 3.0$ & GEA-2 & $1.89 \pm 2.4$ & FEA-2 & $2.21 \pm 2.1$ \\
\hline CEM-1 & $4.17 \pm 0.5$ & GEM-1 & $3.44 \pm 5.0$ & FEM-1 & $2.23 \pm 0.7$ \\
\hline CEM-2 & $4.75 \pm 1.0$ & GEM-2 & $2.66 \pm 0.4$ & FEM-2 & $3.87 \pm 2.0$ \\
\hline
\end{tabular}

${ }^{a} \mathrm{CEA}=$ aqueous barks extract, $\mathrm{CEM}=$ methanol barks extract, $\mathrm{GEA}=$ aqueous twigs extract, $\mathrm{GEM}=$ methanol twigs extract, $\mathrm{FEA}=$ aqueous leaves extract, $\mathrm{FEM}=$ methanol leaves extract, $1=$ rain season, $2=$ dry season. ${ }^{\mathrm{b}} \mathrm{CV}=$ Coefficient of Variation, from triplicate analyses $(\mathrm{n}=3)$.

plant in Amazonia. Bergenin can be used as a standard reference to analyze Endopleura uchi commercial products quality control.

\section{Total phenolic analysis}

Plant phenolic compounds, such as phenolic acids, flavonoids, coumarins, lignins and lignans, tannins and stilbenes are well known. These compounds have presented antioxidant activities by free radical scavenging or neutralization. Besides, they can act by chelating of transition metals. ${ }^{24}$ Therefore, the total phenolic analysis was performed by Folin-Ciocaleau method in Endopleura uchi barks, twigs and leaves aqueous, methanol and ethanol extracts. The results are shown in Table 3 confirm the presence of significantly higher-valued phenolic compounds than those found on other plant species, as reported on all extracts in other studies. ${ }^{25}$ The best results were observed in methanol extracts (38.24-43.02 $\mathrm{mg} \mathrm{GAE} \mathrm{g}^{-1}$ of dry extract), aqueous extracts (23.69-38.94 $\mathrm{mg} \mathrm{GAE} \mathrm{g}^{-1}$ of dry extract) and ethanol extracts (18.43-28.30 $\mathrm{mg} \mathrm{GAE} \mathrm{g}^{-1}$ of dry extract).

\section{Antioxidant activities}

The antioxidant capacity was accomplished through two different methods as a way of attaining better results and avoiding unreal conclusions due to each method's limitations. ${ }^{26,27}$ The aqueous, ethanol and methanol extracts were tested by FRAP (Ferric Reduction Power Assay) and by DPPH free radical scavenging methods according to Table 3 .

Twigs, leaves and barks methanol extracts, respectively, resulted in the highest antioxidant activities by FRAP method. These extracts also presented the best phenolic compounds concentration and, these findings suggest these compounds be responsible for the antioxidant activity achieved by FRAP. ${ }^{28}$ In aqueous extracts the antioxidant activity was higher in leaves (469.99-567.89 mmol $\mathrm{Fe}^{+2} \mathrm{~g}^{-1}$ ), twigs (316.97-359.27 $\mathrm{mmol} \mathrm{Fe} \mathrm{Fe}^{+2} \mathrm{~g}^{-1}$ ) and barks (230.43-239.30 mmol Fe $\left.{ }^{+2} \mathrm{~g}^{-1}\right)$, respectively. Leaves ethanol extracts presented better results $\left(365.38-395.96 \mathrm{mmol} \mathrm{Fe}^{+2} \mathrm{~g}^{-1}\right)$ than barks (241.93-326.53 mmol Fe $\mathrm{mg}^{+2}$ ) and twigs (211.47-290.24 $\mathrm{mmol} \mathrm{Fe}^{+2} \mathrm{~g}^{-1}$ ) ones. Bergenin presented lower values (176.1 $\mathrm{mmol} \mathrm{Fe}^{+2} \mathrm{~g}^{-1}$ ) than Endopleura uchi extracts by FRAP method.

DPPH free radical scavenging capacity by the method is a rapid method to assess the compounds and extracts antioxidant activity. ${ }^{29}$ Our findings were compared with quercetin as a positive control $\left(\mathrm{IC}_{50}=4.50 \mu \mathrm{g} \mathrm{mL}^{-1}\right)$.

Extracts from twigs resulted in the best activities $\left(\mathrm{IC}_{50}=12.08-13.89 \mu \mathrm{g} \mathrm{mL} \mathrm{m}^{-1}\right)$, followed by leaves $\left(\mathrm{IC}_{50}=14.00-20.60 \mu \mathrm{g} \mathrm{mL}^{-1}\right)$ and barks $\left(\mathrm{IC}_{50}=12.04\right.$ to $\left.24.20 \mu \mathrm{g} \mathrm{mL}^{-1}\right)$. Although bergenin is the main extracts component, it presented a low antioxidant activity by DPPH method. The concentration of $1000 \mu \mathrm{g} \mathrm{mL}^{-1}$ inhibits only $33 \%$ of DPPH radical scavenging activity, therefore the concentration to inhibit $50 \%$ should be higher than
Table 3. Total phenolics and antioxidant activities of extracts of Endopleura uchi

\begin{tabular}{|c|c|c|c|}
\hline Extracts $^{\mathrm{a}}$ & $\begin{array}{c}\text { FT } \\
\left(m g \text { GAE }^{\mathrm{b}} \mathrm{g}^{-1}\right. \\
\text { dry extract) }\end{array}$ & $\begin{array}{c}\text { FRAP } \\
\left(\mathrm{mmol} \mathrm{Fe}^{+2} \mathrm{~g}^{-1}\right. \\
\text { dry extract })\end{array}$ & $\begin{array}{c}\mathrm{DPPH} \\
\left(\mathrm{IC}_{50} \mu \mathrm{g} \mathrm{mL} \mathrm{mL}^{-1}\right)\end{array}$ \\
\hline \multicolumn{4}{|c|}{ Barks (value $\pm \mathrm{CV}^{c}$ ) } \\
\hline CEA-1 & $23.69 \pm 3.7$ & $230.43 \pm 0.4$ & $24.20 \pm 1.6$ \\
\hline CEA-2 & $23.94 \pm 1.5$ & $239.30 \pm 0.8$ & $22.13 \pm 0.4$ \\
\hline CEM-1 & $42.49 \pm 0.7$ & $449.47 \pm 0.3$ & $15.63 \pm 2.6$ \\
\hline CEM-2 & $42.17 \pm 0.1$ & $495.55 \pm 0.9$ & $12.04 \pm 0.7$ \\
\hline CEE-1 & $18.43 \pm 2.4$ & $241.93 \pm 0.6$ & $13.89 \pm 0.3$ \\
\hline CEE-2 & $26.49 \pm 1.0$ & $326.53 \pm 0.7$ & $12.51 \pm 2.0$ \\
\hline \multicolumn{4}{|c|}{ Twigs (value $\pm \mathrm{CV}^{\mathrm{c}}$ ) } \\
\hline GEA-1 & $27.94 \pm 1.4$ & $359.27 \pm 0.2$ & $13.89 \pm 4.2$ \\
\hline GEA-2 & $26.04 \pm 4.3$ & $316.97 \pm 1.4$ & $12.36 \pm 1.4$ \\
\hline GEM-1 & $42.16 \pm 2.8$ & $527.85 \pm 0.8$ & $13.62 \pm 0.9$ \\
\hline GEM-2 & $40.03 \pm 1.3$ & $512.58 \pm 1.2$ & $12.08 \pm 2.3$ \\
\hline GEE-1 & $16.69 \pm 1.3$ & $211.47 \pm 1.6$ & $13.51 \pm 1.7$ \\
\hline GEE-2 & $21.68 \pm 0.5$ & $290.24 \pm 1.0$ & $12.38 \pm 1.7$ \\
\hline \multicolumn{4}{|c|}{ Leaves (value $\pm \mathrm{CV}^{\mathrm{c}}$ ) } \\
\hline FEA-1 & $38.94 \pm 2.0$ & $567.89 \pm 2.7$ & $14.76 \pm 1.1$ \\
\hline FEA-2 & $35.86 \pm 1.6$ & $469.99 \pm 0.6$ & $18.40 \pm 0.9$ \\
\hline FEM-1 & $43.02 \pm 2.6$ & $512.39 \pm 0.9$ & $14.00 \pm 1.7$ \\
\hline FEM-2 & $38.24 \pm 3.1$ & $476.35 \pm 1.8$ & $20.36 \pm 0.3$ \\
\hline FEE-1 & $32.46 \pm 2.9$ & $395.96 \pm 0.4$ & $17.50 \pm 0.3$ \\
\hline FEE-2 & $28.30 \pm 1.4$ & $365.38 \pm 0.5$ & $20.60 \pm 1.5$ \\
\hline \multicolumn{4}{|c|}{ Standard (value $\pm \mathrm{CV}^{\mathrm{c}}$ ) } \\
\hline Quercetin & - & - & $4.50 \pm 0.4$ \\
\hline Bergenin & - & - & $>1000$ \\
\hline
\end{tabular}

${ }^{a} \mathrm{CEA}=$ aqueous barks extract, $\mathrm{CEM}=$ methanol barks extract, $\mathrm{CEE}=$ ethanol barks extract, GEA = aqueous twigs extract, $\mathrm{GEM}=$ methanol twigs extract, GEE $=$ ethanol twigs extract, FEA $=$ aqueous leaves extract, $\mathrm{FEM}=$ methanol leaves extract, FEE $=$ ethanol extract of leaves, $1=$ rain season, $2=$ dry season. ${ }^{\mathrm{b}} \mathrm{GAE}=$ gallic acid equivalent. ${ }^{\mathrm{c} C o e f f i c i e n t}$ of Variation $(\mathrm{CV})$, from triplicate analyses $(n=3)$.

$1000 \mu \mathrm{g} \mathrm{mL}^{-1}$ that is considered no significant antioxidant activity. According to Subramanian et al. ${ }^{30}$ bergenin showed mild activity by the methods of DPPH, FRAP and nitric oxide inhibition. The antioxidant activity of extracts by DPPH method suggests Endopleura uchi extracts' potential antioxidant activity when compared with the leaves' commercial extracts from Ginkgo biloba $\left(\mathrm{IC}_{50}=40 \mu \mathrm{g} \mathrm{mL}^{-1}\right)$ 
and other Brazilian plants used as antioxidants..$^{25}$ The hydroxyl groups from phenolic compounds as flavonoids, phenolic acids, tannins, and other compounds can be responsible for these antioxidant activities. ${ }^{31-33}$

\section{LPS-induced NO production inhibition}

According to traditional medicine, the species Endopleura uchi is mainly used for the treatment of menstrual disorders and uterine inflammation, therefore its effect on the aqueous extracts, chloroform and ethyl acetate fractions inflammatory response through production of inflammatory mediators by LPS-induced in murine macrophage cells (J774), has been ascertained. It measured the ability to inhibit inflammatory mediators NO production..$^{23}$ Macrophage cells were exposed to LPS for NO-stimulation and treated with extracts and fractions in the concentration of $25 \mu \mathrm{g} \mathrm{mL}^{-1}$. The tested samples showed cytotoxicity at concentrations above $100 \mu \mathrm{g} \mathrm{mL} \mathrm{m}^{-1}$, so $25 \mu \mathrm{g} \mathrm{mL}{ }^{-1}$ was considered safe to test the samples. The negative control (cells + LPS) produced $8.5 \mu \mathrm{m}$ of NO and the positive control (PC) (cells) produced $0.1 \mu \mathrm{m}$ of the inflammatory mediator. The results showed cells treated with the extracts and fractions of Endopleura uchi to produce a significant inhibition (Figure 2). The best results were observed in leaves chloroform fractions (FEMC), twigs ethyl acetate (GEMAc) and chloroform (GEMC) fractions and bark chloroform fraction (CEMC) resulting in $0.1,0.5,0.6$ and $0.6 \mu \mathrm{m}$ of NO respectively in LPS-induced NO production. The other extracts and fractions obtained NO production between 1.4-3.5 $\mu \mathrm{m}$, below the negative control ( $8.5 \mu \mathrm{m}$ of $\mathrm{NO})$. When assessing the inhibitory capacity one finds the chloroform fractions of the leaves (FEMC) and bark (CEMC) de Endopleura uchi to be the most active in producing $\mathrm{IC}_{50}=3.2$ and $4.8 \mu \mathrm{g} \mathrm{mL}^{-1}$ respectively. The remaining extracts and fractions showed values between $\mathrm{IC}_{50}=7-12 \mu \mathrm{g} \mathrm{mL}-1$ (Figure 3 ).

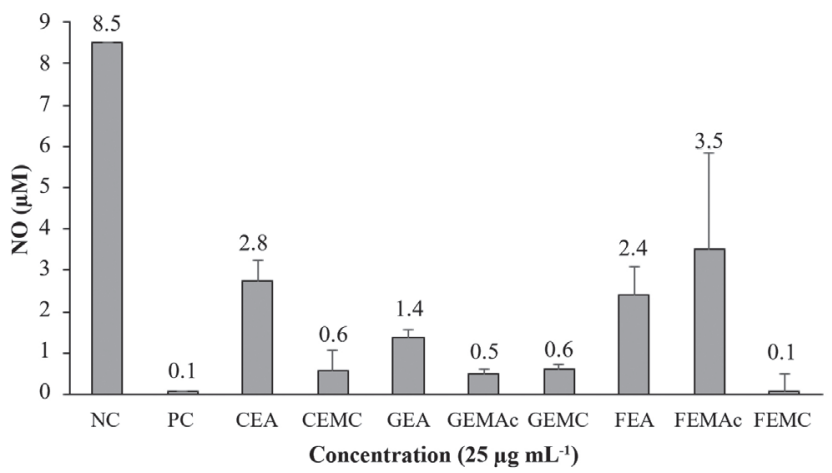

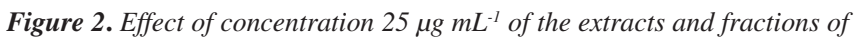
Endopleura uchi in the production of $\mathrm{NO}$ in culture of macrophages stimulated by LPS. Values are expressed as mean \pm standard deviation obtained from analyzes in triplicate $(n=3) . N C=$ negative control; $P C=$ positive control; $C E A=$ aqueous barks extract; $C E M C=$ barks chloroform fraction; $G E A=$ aqueous twigs extract; GEMAc = twigs ethyl acetate fraction; $G E M C=$ twigs chloroform fraction; FEA = aqueous leaves extract; $F E M A c=$ leaves ethyl acetate fraction; FEMC = leaves chloroform fraction

Studies show evidence that the NO molecule, when produced in excess, can contribute to certain pathological conditions such as rheumatoid arthritis, ${ }^{34}$ Alzheimer's and Parkinson's ${ }^{35}$ diseases among others, therefore there is growing demand for substances capable of attenuating the NO production, which may have estimable therapeutic value in the treatment of excess nitric oxide-induced pathophysiological conditions. ${ }^{36}$ The results indicate the extracts and fractions of Endopleura uchi to show NO inhibitory effect, therefore, it can be regarded as sources of active substances in the treatment of

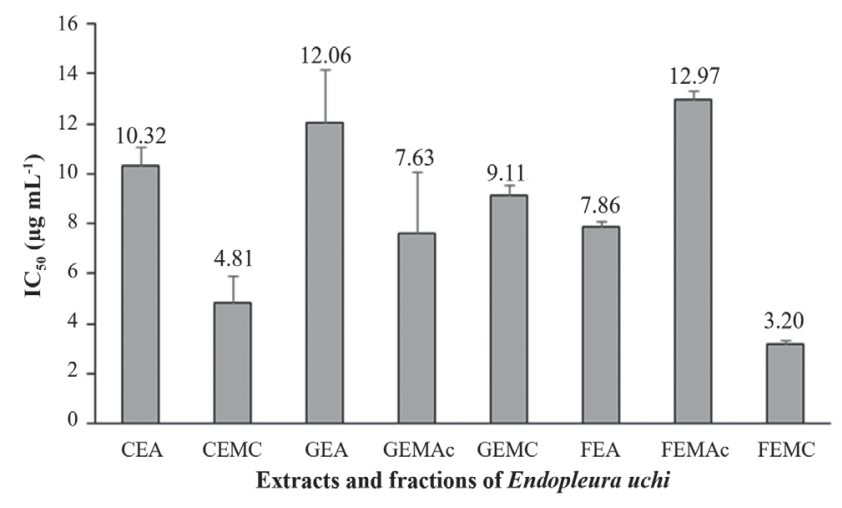

Figure 3. Inhibitory capacity $\left(I C_{50}\right)$ of $N O$ induced by LPS in $J 774$ murine macrophage extracts and fractions. The data are represented as mean \pm standard deviation. CEA = aqueous barks extract; $C E M C=$ barks chloroform fraction; $G E A=$ aqueous twigs extract; $G E M A c=$ twigs ethyl acetate fraction; $G E M C=$ twigs chloroform fraction; $F E A=$ aqueous leaves extract; FEMAc = leaves ethyl acetate fraction; FEMC = leaves chloroform fraction

inflammatory processes. These findings should be taken into account for the isolation and identification of these active substances.

\section{CONCLUSIONS}

Since the findings showed to be positive for antioxidant activity by iron reduction, DPPH radical scavenging capacity methods, as well as an anti-inflammatory activity through NO suppression, they suggest that species Endopleura uchi can be considered an important plant material bearing therapeutic potential. Quantification showed a significant amount of bergenin in its leaves and twigs, indicating that the substance bearing different biological activities may be attained from other plant parts apart from the barks. These findings can serve as the basis for preparing antioxidant and anti-inflammatory compounds that may contribute to the safer use of this plant species along with the development of possible herbal products.

\section{SUPPLEMENTARY MATERIAL}

Figures related to the results of some experiments used in this article are in the supplementary material that is available in http:// quimicanova.sbq.org.br in the form of an open PDF file.

\section{ACKNOWLEDGEMENTS}

This work conducted by the financial support from CAPES and CNPq (CT-Amazonia/MCT No 55/2008 Proc. No 575503/2008-4). The authors also thank the post-graduate in Chemistry and Pharmacy of the Federal University of Amazonas, to the Federal Institute of Amazonas for support and collaboration and the CBA by NMR analysis.

\section{REFERENCES}

1. Cuatrecasas, J. Em A taxonomic revision of Humiriaceae; Cuatrecasas, J., ed.; Smithsonian Institution: Washington, D.C, 1961, Vol. 35.

2. Kinupp, V. F. Em Plantas Alimentícias Não Convencionais (PANC) no Brasil: guia de identificação, aspectos nutricionais e receitas ilustradas; Kinupp, V. F., Lorenzi, H., eds.; Instituto Plantarum de Estudos da Flora: São Paulo, 2014.

3. Revilla, J. Em Plantas da Amazônia - Oportunidades Econômicas e Sustentáveis; Revilla, J., eds.; Instituto Nacional de Pesquisas da Amazônia/SEBRAE: Manaus, 2002. 
4. Antonisamy, P.; Duraipandiyan, V.; Ignacimuthu, S.; J. Pharm. Pharmacol. 2011, 63, 1070.

5. Nazir, N.; Koul, S.; Qurishi, M. A.; Najar, M. H.; Zargar, M. I.; Eur. J. Med. Chem. 2011, 46, 2415.

6. Silva, S. L.; Oliveira, V. G.; Yano, T.; Nunomura, R. C. S.; Acta Amazonica 2009, 39, 187

7. Nunomura, R. C. S.; Oliveira, V. G.; Silva, S. L.; Nunomura, S. M.; J. Braz. Chem. Soc. 2009, 20, 1060

8. Sumino, M.; Sekine, T.; Ruangrungsi, N.; Igarashi, K.; Ikegami, F.; Chem. Pharm. Bull. 2002, 50, 1484.

9. Lim, H. K.; Kim, H. S.; Choi, H. S.; Oh, S.; Choi, J.; J. Ethnopharmacol. 2000, 72, 469.

10. Takahachi, H.; Kosaka, M.; Watanabe, Y.; Nakade, K.; Fukuyama, Y.; Bioorg. Med. Chem. 2003, 11, 1781.

11. Piacente, S.; J. Nat. Prod. 1996, 59, 565.

12. Prithiviraj, B.; Singh, U. P.; Manickam, M.; Srivastava, J. S.; Ray, A. B.; Plant Pathol. 1997, 46, 224.

13. Silva, T. B. C.; Alves, V. L.; Mendonca, L. V. H.; Conserva, L. M.; da Rocha, E. M. M.; Andrade, E. H. A.; Lemos, R. P. L.; Pharm. Biol. 2004, 42, 94

14. Ogan, A. U.; Phytochemistry 1971, 10, 2832.

15. Scandalios, J. G.; Braz. J. Med. Biol. Res. 2005, 38, 995.

16. Nathan, C.; FASEB J. 1992, 6, 3051.

17. Filizola, B. C. Em Boas Práticas de Manejo para o Extrativismo Sustentável de Cascas; Filizola, B. C., Sampaio, M. B., eds.; Instituto Sociedade, População e Natureza, Brasília, 2015.

18. Almeida, M. F. O.; Melo, A. C. R.; Pinheiro, M. L. B.; Silva, J. R. A.; Souza, A. D. L.; Barison, A.; Campos, F. R.; Amaral, A. C. F.; Machado, G. M. C.; Leon, L. L. P.; Quim. Nova 2011, 34, 1182.

19. Magalhães, L. A. M.; Lima, M. P.; Marinho, H. A.; Ferreira, A. G.; Acta Amazonica 2007, 37, 447.
20. Velioglu, Y. S.; Mazza, G.; Gao, L.; Oomah, B. D.; J. Agric. Food Chem. 1998, 8, 4113.

21. Mensor, L. L.; Menezes, F. S.; Leitão, G. G.; Reis, A. S.; Dos Santos, T. C.; Coube, C. S.; Leitão, S. G.; Phytother. Res. 2001, 15, 127.

22. Luximon-Ramman, B. T.; Soobratee, M. A.; Aruoma, O. I.; J. Agric. Food Chem. 2002, 50, 5042.

23. Verma, N.; Chakrabarti, R.; Das, R. H.; Gautam, H. K.; J. Complementary Integr. Med. 2012, 9, 1.

24. Naczk, M.; Shahidi, F.; J. Chromatogr. A 2004, 1054, 95.

25. Sousa, C. M. M.; Silva, H. R.; Vieira-Jr., G. M.; Ayres, M. C. C.; da Costa, C. L. S.; Araújo, D. S.; Cavalcante, L. C. D.; Barros, E. D. S.; Araújo, P. B. M.; Brandão, M. S.; Chaves, M. H.; Quim. Nova 2007, 30, 351.

26. Ayoola, G. A.; Ipav, S. S.; Sofidiya, M. O.; Adepoju-Bello, A. A.; Coker, H. A. B.; Odugbemi, T. O.; Int. J. Health Res. 2008, 1, 87

27. Wong, S. P.; Leong, L. P.; Koh, J. H. W.; Food Chem. 2006, 99, 775.

28. Amarowicz, R.; Pegg, R. B.; Rahimi-Moghaddam, P.; Barl, B.; Weil, J. A.; Food Chem. 2004, 84, 551

29. Brand-Wiliams, W.; Cuvelier, M. E.; Berset, C.; Food Sci. Technol. 1995, $28,25$.

30. Subramanian, R.; Subbramaniyan, P.; Raj, V.; BJBAS 2015, 4, 256.

31. Polterait, O.; Curr. Org. Chem. 1997, 1, 415.

32. Li, H. B.; Wong, C. C.; Cheng, K. W.; Chen, F.; LWT -- Food Sci. Technol. 2008, 41, 385

33. Barros, L.; Ferreira, M. J.; Queirós, B.; Ferreira, I. C. F. R.; Baptista, P.; Food Chem. 2007, 103, 413.

34. Sakurai, H.; Kohsaka, H.; Liu, M. F.; Higashiyama, H.; Hirata, Y.; Kanno, K.; Saito, I.; Miyasaka, N.; J. Clin. Invest. 1995, 96, 2357.

35. Calabrese, V.; Boyd-Kimball, D.; Scapagnini, G.; Butterfield, D. A.; In Vivo 2004, 18, 245

36. Hobbs, A. J.; Higgs, A.; Moncada, S.; Annu. Rev. Pharmacol. Toxicol. 1999, 39, 191. 